\title{
Technical issues and energy efficient adaptive reuse of heritage listed city
}

\section{halls in Q ueensland A ustralia.}

\begin{abstract}
Purpose - A daptive reuse of heritage stock several advantages: retention of culturally and socially significant buildings, as well as the opportunity to consider embodied energy, energy efficiency retrofit measures and other environmental upgrades. This paper identifies the technical issues faced in the adaptive reuse of Australian heritage listed city halls and discusses sustainable strategies to enable further adaptations to be more energy efficient.
\end{abstract}

Design/methodology/approach - Adaptive reuse of a heritage building provides an opportunity to retain embodied energy, improve energy efficiency and enhance durability, which are important aspects of the technical lifecycle of a building. Using a case study methodology and a qualitative approach, this paper evaluates adaptations and the technical isues faced in three heritage city halls in Queensland, A ustralia.

Findings - The analysis shows that enhancing energy efficiency enables heritage buildings to reduce their climate change impacts. However, the installation of equipment for energy efficiency can pose technical issues for heritage buildings. The ownership of heritage building and interest of the local community affects the solutions that are viable. Solutions and further sustainable strategies are proposed through analysis of case studies.

Originality/value - City halls globally adopt different and varied architectural designs, features, and scales. They are often heritage listed and locally significant landmarks that have undergone various adaptations; however, they have been overlooked in much adaptive reuse research, particularly in A ustralia. City halls differ from other heritage buildings in their collective sense of ownership which is important in regard to proposed changes, as citizens have an interest and hold opinions which may affect measures adopted. This paper contributes to the body of knowledge related to energy efficient technical adaptive reuse of city halls.

K eywords - heritage city halls, adaptation, adaptive reuse, climate change, technical issues, energy efficiency

Paper type - Case study

\section{Introduction}

"H eritage conservation contributes to creating a sustainable built environment and resilient communities"

(M TBA, 2016)

A sustainable built environment and resilient communities are essential to the continuing wellbeing of humankind and the liveability of the planet. Climate change plays an important role in environmental degradation and needs to be mitigated to reduce its negative effects on the natural and built environment. Collectively, buildings are responsible for the largest consumption of energy in use and construction through embodied energy and greenhouse gas emissions, and are a source of environmental waste (K elly, 2009). Whilst we can influence environmental attributes in new building stock through energy efficiency in regulations, new construction consumes high levels of energy and with only $1 \%$ typically added each year to 
the total stock of buildings, it follows we should look at the potential to retrofit or adapt existing buildings in order to make them more energy efficient and take the opportunity to retain their embodied energy (K elly, 2009). Enhancing and upgrading the performance of exisiing buildings is significant in mitigating climate change (M TBA, 2016).

A daptive reuse has been defined by many authors, all of whom agree that the practice involves a spectrum of changes from maintaining the building due to its values to changing the overall function of a building for other uses ( $Y$ azdani M ehr et al., 2016). A daptive reuse is seen as a strategy to achieve environmental sustainability and reduce energy consumption (van der Flier $\&$ Thomsen, 2006). A daptive reuse can decrease energy use, greenhouse gas and carbon emissions through embodied energy retention, thus contributing to sustainability practice (Conejos, 2013). Further, reusing building materials can retain up to $95 \%$ of embodied energy (Binder, 2003). Technical adaptation of heritage buildings is an important means of achieving sustainability and energy efficiency; however, some heritage buildings seem inflexible in terms of technical innovation and upgrade, and generate technical challenges (Bullen \& L ove, 2011). This paper identifies and evaluates technical challenges in the energy efficient adaptive reuse of three A ustralian heritage listed city halls. The questions addressed are, what are the technical issues faced in adaptive reuse/adaptation and secondly, what other sustainability measures could be adopted?

\section{I mportance of C ity Halls}

City halls have changed as a result of the growth of cities, towns, municipalities, and shires. Regardless of architectural style, size and location, these buildings share one aspect, which is the building is, or was, the seat of political power, symbolising initial settlement and establishment of local governance in an area (Chattopadhyay \& W hite, 2014). City halls serve local government and the community, thus possessing distinctive psycho-social features through their strong associative memories among the community.

In A ustralia, city halls are common features in the built heritage environment. The function and usability of city/town halls have changed due to population growth and changes to local government boundaries. Under these circumstances, adaptive reuse and adaptation are important strategies to keep these buildings viable (Wills, 2011). However, there is little empirical research on the physical and technical attributes of city halls and the potential for adaptation to enhance sustainability by reducing energy consumption and greenhouse gas emissions. With heritage listing, further restrictions apply in terms of interventions that are permissible and this paper focuses on technical adaptation of A ustralian city halls.

\section{Technical adaptation of heritage buildings}

Technical lifespan is an important indicator of a building's age and its continuous lifecycle. The technical lifecycle is a period of time in which a building can not only meet the required physical and technical needs of the users, but also provide and protect health and safety of the occupants. With technical obsolescence, a building may lose its value and usability, and; is likely to become partially or fully vacant (W ilkinson et al., 2014). Technical obsolescence and the additional operational costs associated with poor energy efficiency can make retention unappealing, thus risking demolition (Langston, 2008). Technical factors play an important role in making decisions related to adapting or redeveloping a building. The reason being, is that some technical issues are hidden, difficult to access, expensive to fix, or may have a 
negative effect on the appearance of heritage buildings (D ouglas, 2006). Therefore, a building has to be able to accomodate users new technical requirements to be a successful case for adaptive reuse (W ilkinson et al., 2014).

A daptive reuse of heritage buildings not only helps save energy and provides a pleasant indoor environment, but it al so reduces use of materials and their impact on the environment (M TBA, 2016). In technical upgrade and adaptive reuse of old buildings energy efficiency is an important consideration. However, there is no common approach for improving energy efficiency in heritage buildings due to different adaptation perspectives, for example, what is acceptable from an environmental point of view, may not be acceptable from a heritage view point as it may threaten heritage values ( $V$ ieveen, 2013). To have a positive impact on the environment and climate change respectively, existing buildings should retain as much structure as possible, whilst their services and systems need to be improved in terms of lighting, ventilation, water, glazing, and HV AC (A bdullah et al., 2015).

Historically buildings were not designed to be energy efficient, though some were designed to work with the climate, with shading and overhanging eaves deflecting direct heat from facades keeping interiors cooler. A s such energy consumption can be higher, especially when compared to new er code compliant or 'green' buildings. M ore consideration should be given to enhancing energy efficiency standards in the adaptive reuse of old buildings (Conejos et al., 2011). Improving energy efficiency of old buildings should be based on carbon, energy and financial costs, although M enzies (2011) noted other factors should not be underestimated such as social and cultural values for heritage buildings which have an important role in presenting identity. Conejos et al (2011) stated that adaptive reuse improves operational energy of old buildings in terms of mechanical improvements such as installation of air conditioning systems, whilst preserving their heritage and cultural values for present and future generations. Furthermore, technical solutions in adaptive reuse may vary based on building type and structure; some technical solutions which seem appropriate for old buildings may not be suitable for heritage buildings (M enzies, 2011). Plevoets (2014) classified the technical challenges of adaptive reuse in three main categories based on previous studies and are summarised in Table 1.

\section{Table 1}

This study examines technical issues related to comfort, safety, and energy efficiency with focus on thermal performance and indoor air quality.

\section{Research M ethodology}

Case study is a qualitative research method which allows in-depth study and enables the researcher to study a subject in detail through a specific context (Zainal, 2017); here adaptation of heritage city halls in Queensland for energy efficiency. Case study is a preferable method to answer "how" or "why" questions, especially when the emphasis is on current actual practices. Therefore, case study methodology provides a complete understanding of events in reality (Y in, 2017). With adaptive reuse research, many authors adopt a case study methodology to achieve detailed and in-depth analysis of cases (Conejos, 2013; Langston, 2012; Wilkinson, 2011; W ilkinson et al., 2014). Therefore, to achieve a holistic understanding of technical issues in adaptive reuse, three heritage listed city halls were selected for this research.

Interviews were conducted as a primary data collection method. Taylor and Bogdan (1984) noted interviewing is a method which helps the researcher to achieve a deeper understanding of issues that cannot be directly examined. To validate the findings, interviews were organised with construction professionals involved in the adaptive reuse to collect detailed information 
and to clarify the technical issues and solutions adopted. For this research, the interviewees were given a topic guide mainly focused on the barriers to adaptive reuse of heritage listed city halls. The interview method followed the archival research and on-site research to generate new knowledge and provide in-depth analysis.

The city halls are located in different regions of Q ueensland, A ustralia and were selected based on two categories; "adaptive reuse" and "adaptation". Through adaptive reuse the function of the building changes for other functions and purposes; whereas with adaptation, the original function of the building is retained. For these cases, regardless of whether their functions changed or not, some technical challenges were encountered due to their age which made them suitable for this study.

Technical challenges were identified and evaluated based on the literature summarised in Table 1. Case study one is Rockhampton City Hall in Central Queensland which underwent adaptation. South B risbane M unicipal Chambers in South East Queensland, the second case study, underwent adaptive reuse. The third case study, Toow oomba City Hall in the Darling Downs, South W est Queensland al so underwent adaptation. All cases are selected are located in Queensland, A ustralia; however the result of this research may be applicable to other city halls in A ustralia due to their common charactristics.

\section{The case study buildings}

Rockhampton City Hall

This hall was constructed from 1939 to 1941 using brick and concrete on a granite base (Figure 1) (Maryborough Chronicle, 1938). The building was analysed based on archival sources including the Conservation $\mathrm{M}$ anagement $\mathrm{Plan}$, on-site observation and research and interviews. The interviews were conducted with the architect, Project Officer Communities and Facilities, and the Coordinator Facilities who were experienced and knowledgeable about the adaptation of the building and its challenges.

Figure 1

The design of the original building was based on natural light and ventilation, with external verandas around the building. However, subsequently the verandas were enclosed and converted to office spaces. Cook (2017b) stated that provision of natural lighting and ventilation in the original design were important features in terms of energy efficiency; however, these aspects were no longer supported after the installation of walls and a mezzanine floor in the reception hall, enclosing of the verandas, the construction of solid partitions, and the rearrangement of original partitions (Cook, 2017b). These al terations led to the provision of technical building services such as air conditioning and upgrading of lighting systems. The technical adaptation of the building resulted in some technical challenges shown in Table 2 (Blake, 2008). 
Enclosing the verandas had a negative effect on thermal comfort and necessitated the installation of air-conditioning system to meet user expectations regarding comfort. A fan coil system was installed with an outdoor condensing unit. The challenge of installing the AC was finding a suitable location to position the external condensing units without al tering the heritage values of the building (Toohey, 2017a). Due to the weight and load of the condensing units, they were installed on freestanding platforms to the rear of the building and impacted negatively on the appearance of the heritage façade.

Currently, there are a large number of old AC units in the building (Somerville, 2017) which leak and the offices in the former veranda areas become wetted during rainfall because the rainwater downpipes are located in their original position, now inside the building (Cook, 2017a). Therefore the AC systems were not working properly and they should be upgraded to energy efficient ones while preserving aesthetic values of the building. The Heritage Department made recommendations to remove the walls enclosing the verandas to return the building to its original naturally ventilated state (Somerville, 2017; Toohey, 2017b). The potential return to natural ventilation may have an effect on the selection of the air-conditioning system which needs to be integrated effectively with regards to energy efficiency.

The verandas were enclosed using the same materials as the original building to preserve heritage, architectural, and aesthetic values. However, the windows were not energy efficient since they had defective glazing which resulted in rain penetration, heat gain and provided a poorly ventilated work environment (Blake, 2008). Furthermore enclosing the verandas led to the need for artificial lighting. Energy-efficient and sustainable LED lighting was installed to increase energy efficiency.

Preservation and adaptation of the building allows the retention of embodied energy in the materials and structure, which results in the reduction of energy use and resources. However, being heritage listed, any work means modern regulations and restrictions related to heritage listed buildings have to be upheld. On this basis, the building should be restored to the climatically appropriate, original design in terms of opening the verandas for natural light and ventilation, whilst adopting modern state of the art energy efficient mechanical and electrical standards.

\section{South Brisbane Municipal Chambers}

The two storey building was constructed in 1891-92 of red brick, sandstone, and marble in the free classical style known as Italianate Classical Revival (Figure 2) (The Queensland Government, 2016a). The building was analysed through archival research, on-site research, reference to the Conservation $\mathrm{M}$ anagement Plan, and an interview with the archivist.

Figure 2

The chambers were designed mostly based on daylighting and natural ventilation. The lighting of the staircase was provided by a very large window and the council chambers had three large windows providing daylighting (The B risbane Courier, 1892). However, in its conversion to the Conservatorium of M usic during the 1950s, the alteration works involved demolition of interior walls and installation of mechanical air ventilation and soundproofing of doors and windows (The Courier M ail, 1955). A ir-conditioning equipment was installed and located in 
the basement of the building and the ventilated air was carried through the building in several ducts. In some areas, false ceilings were installed to conceal the ductwork (Allom Lovell, 2001).

In 1999, South Brisbane Municipal Chambers was reused as the Somerville House Administration centre. Bottger (2016) noted that when Somerville House purchased the building, it was in very poor condition and required considerable refurbishment to render it useable. The ceiling had been removed by the Conservatorium of M usic to install an air-flow system. The fans were hung from a false ceiling, which was installed to solve acoustic issues. Introducing air conditioning into the building was complicated and difficult to achieve 'invisibility' (Bottger, 2016). To meet user demand, the air-conditioning system has been installed with the outdoor condensing units on the façade of the building, impacting its visual value. South Brisbane M unicipal Chambers adaptation and technical challenges over time are shown in Table 3.

Table 3

Upgrading the technical services of the building has caused past and ongoing challenges. In preserving the South B risbane M unicipal Chambers heritage values have been preserved for future generation and the embodied energy of materials and the structure have been retained, which contribute to reductions of lifecyle energy use and mitigation of climate change. Based on a site inspection, research and the interview, the building is not yet energy efficient as there have been no improvements to windows, doors and insulation because of changed current ownership needs. Further technical adaptations are required to make the building energy efficient with improvements related to fixtures, materials and structure.

Toowoomba City Hall

This two-storey brick structure, constructed in 1900, is located in the Darling Downs/ South W est Queensland (Figure 3) (L M arquis, 1992). The building was analysed through archival research, on-site research, reference to the Conservation $M$ anagement Plan, and interviews with the architect, project manager and engineer.

Figure 3

This building underwent alterations and additions over-time due to different requirements and standards. During the mid-1930s, the need to upgrade the theatre arose, when local musical and theatrical groups complained the ventilation did not work (L M arquis, 1992). Although the building was designed to work with the climate using available technology at the time, it was not successful in satisfying occupants over time and needed upgrading based on user demands. During the 1937 refurbishment, the ventilation was improved and skylights were installed to light the art gallery and main stairs (The Queensland Government, 2016b). This enabled the 
building to use natural light. A daptations and technical challenges to Toow oomba City Hall are listed in Table 4.

Table 4

Introducing modern technologies into an old building, such as ventilation and air-conditioning, is a challenge especially for buildings designed to use natural light and ventilation. Here installation of the ventilation system was an issue with getting equipment into the building and the roof had be removed. Creating 3D models helped with the installation of the ventilation system. The chiller was located on the roof, and was concealed by constructing parapets to preserve the visual value of the building (Sims, 2016). The building's materials have high thermal mass with thick brick cavity external walls, which previously helped the natural ventilation of the building, however the current users prefer mechanical systems to provide thermal comfort. A C was installed in 1995 to meet user needs. By 2017, the A C system did not work efficiently and could not be repaired due to financial issues. Although all original windows are openable, staff cannot open them as this undermines the AC system (Adam, 2016). The windows are original Art Deco ornate timber windows, which need to be doubleglazed for acoustic and thermal insulation (Sims, 2016). The theatre was the only part of the building which underwent adaptation based on sustainability and the rest of the building needs to undergo improvements to be energy efficient.

The building was not insulated originally, however there was a big roof space which has been insulated with floor insulation. Furthermore, the architect specified $50 \mathrm{~mm}$ high density polyester acoustic materials to the theatre walls, which provided insulation (Sims, 2016). The architect (Sims, 2016) felt these changes may cause some level of loss in heritage value of the building.

Toow oomba City Hall was designed to use natural light and ventilation which is an energy efficient design in our contemporary understanding. However, user expectations changed over time which resulted in some changes to the building. The architect tried to renovate the theatre based on sustainability standards to meet user needs in spite of the challenges. The building needs further technical adaptation.

\section{Analysis of technical issues}

$M$ any heritage buildings were constructed when energy costs were low and there was no concern about climate change. Enhancing energy efficiency in old buildings is considered one important opportunity to mitigate climate change (A bdullah et al., 2015; M TBA, 2016). The different case studies with different uses, different owner preferences and different characteristics provide a detailed analysis of the technical upgrades and their respective challenges.

Table 5 shows the common technical issue shared by the three heritage city halls related to finding a suitable place to install the AC system, al so identified by Douglas (2006). Insulation has not been improved in Rockhampton City Hall and South Brisbane M unicipal Chambers and they need further improvements to enhance energy efficiency. A II these city halls upgraded the lighting to LED which has higher efficiency and longer life, leading to energy savings and reduction of carbon deoxide emissions (A hn et al., 2014). The retrofitting of lights did not pose 
any challenge. The usage and ownership of a heritage building play important roles in considering technical challenges and solutions.

Table 5

A daptation of these heritage buildings resulted in some technical challenges (Table 6). Introduction of modern services into old buildings is difficult due to age and the need to comply with current building codes. There is no general guideline for adaptive reuse of heritage buildings, although they will need to be compliant with current building codes when adapted. There are no general and international rules, codes, and standards for energy adaptation of heritage buildings and so, each country has its own rules relating to energy efficiency requirements which exclude or include existing buildings (M azzarella, 2015). B aek and Park (2012) stated the lack of regulatory systems is one of the challenges of improving the energy performance of existing buildings. This poses a challenge in terms of policy, since the technical upgrade and issues vary case by case. Table 6 shows the existing or inherent energy efficient services for each building, and the technical changes and challenges each experienced during its lifecycle, along with proposed key strategies for further energy efficient adaptation.

Table 6

The building envelope, which is in direct contact with the external environment, is used for lighting, cooling, heating and ventilation. Therefore, it is an important factor for energy measurements and defined as the "interface of energy losses" (A bdullah et al ., 2015). A s shown in Table 6, the three heritage city halls were constructed with durable masonry walls, such as stone, brick and concrete, which have high thermal mass. Thermal mass provides the opportunity to regulate the temperature inside a building. Staff and occupant activities produce heat, which can be absorbed by the thermal mass of the walls. In addition embodied energy will be saved by reusing existing walls and structure with good thermal mass. Pisello (2016) stated most older buildings were built with poor performing envelopes and inadequate energy systems, which is the case with these city halls. Therefore, external walls need upgrading, especially in terms of thermal insulation, but with no changes to their appearance becuase of their heritage status. Webb (2017) noted energy retrofitting on heritage buildings should involve assessments regarding materials and the visual impacts on heritage value. This may lead to placing insulation within a cavity (when provided) or on the internal face of the wall to preserve the exterior visual value of heritage buildings. M ortar joints need to be repointed carefully to provide air barriers and reduce the risk of water penetration and heat loss or gain. Windows, and the joints around openings also need to be improved to decrease infiltration. In these city halls, the window frames were mostly old and require al terations to make them more functional. O ptions include installing polycarbonate frames, energy panels and thermal-panes as secondary glazing or replacing windows with double glazed units. A II fenestration needs to be sealed and airtight to prevent energy waste. Martínez-M olina et al (2016) found that replacing or adding insulation to existing windows and doors reduced energy demand and consumption. However, for heritage buildings any replacement would affect their heritage values. In the three case studies the staircase, atrium, and skylight are considered as a passive 
system which provide natural light and ventilation. However, natural ventilation alone cannot meet the users' comfort and it needs to be part of a hybrid system to be energy efficient (Pisello et al., 2016). Providing energy efficient systems in these city halls lead to reductions of energy consumption and increased environmental sustainability.

Energy efficiency retrofitting of heritage buildings is important for improving sustainability and preserving the built heritage of historic structures (M artínez-M olina et al., 2016). These city halls have experienced energy efficient adaptation in different ways; however, they still need further technical adaptation in the form of the introduction and installation of active and passive energy efficiency systems, such as window retrofitting, internal envelope insulation, installation of control systems, and the use of renewable energy including solar and geothermal power systems.

\section{Conclusion}

Old buildings have often many inherent sustainability features in terms of embodied energy, embodied carbon, durable materials, and even design and construction techniques. However, user expectations change over time in terms of technical standards and comfort levels. Under such circumstances, old buildings need to undergo modification and modernisation to meet the current expectations. R etrofitting existing buildings is a way of addressing the climate change (M iller and Buys, (2008). Reduction of greenhouse gas emissions is important to mitigate global warming and climate change and, it is a responsibility of stakeholders to find ways to reduce emissions from existing buildings (J agarajan et al., 2017).

The research questions addressed were; what are the technical issues faced in adaptive reuse / adaptation and secondly, what other sustainability measures could be adopted? This research analysed the technical issues in the energy efficient adaptation of three heritage listed city halls through a case study approach, using interviews, combined with on-site and archival research. This research analysed technical changes and challenges of these heritage buildings, how the issues were resolved, and idenitifed sustainable strategies for further work. However, there might be more sustainable options for energy retrofit of heritage buildings, which needs further study.

The three case studies had technical challenges in terms of providing insulation, acoustic performance, and finding suitable places to locate and fit AC without compromising architectural integrity and visual quality of the building, which is important in all heritage buildings regardless of use. The results of this research will be applicable for other heritage buildings sharing similiar characteristics. The technical needs and requirements of city halls have a direct interaction with the building user and owner preferences, which makes city halls different from other heritage building types. Each community had slightly different user requirements for their buildings; for example, the Toowomba City Hall had issues around acoustic performance to make it acceptable for the community use there, whereas the Rockhampton City Hall uses meant that acoustic performance was not important for those users'.

W ebb (2017) noted improving energy efficiency in heritage buildings must be balanced with preserving heritage values to have long-term continued use. Whilst sustainable improvements should preserve heritage values as much as possible; there might be some level of loss to make a heritage building liveable and usable. Therefore, for any work on heritage buildings there 
should be a comprehensive understanding of the cultural and heritage values of the building along with its physical characteristics. Understanding of the original energy design of an old building will enable architects to find better solutions for restoring their energy features.

\section{R eferences}

A bdullah, A., Perkins, \& Will. (2015). Adaptive Reuse: Energy Efficiency and Sustainability Measures.

A dam, A. (2016). A daptive reuse of Toow oomba City Hall. In S. Y. M ehr (Ed.), PhD Gold Coast, A ustralia: Griffith U niversity.

A hn, B.-L., Jang, C.-Y ., Leigh, S.-B., Y 00, S., \& J eong, H. (2014). Effect of LED lighting on the cooling and heating loads in office buildings. Applied Energy, 113, 1484-1489.

Allom Lovell, A. (2001). Former South Brisbane M unicipal Chambers, A conservation plan for Somerville H ouse. Retrieved from B risbane, A ustralia:

Baek, C., \& Park, S. (2012). Policy measures to overcome barriers to energy renovation of existing buildings. Renewable and Sustainable Energy Reviews, 16(6), 3939-3947.

Binder, M. L. (2003). Adaptive reuse and sustainable design: a holistic approach for abandoned industrial buildings. University of Cincinnati,

Blake, T. (2008). Rockhampton City Hall Conservation Management Plan. Retrieved from A ustralia:

Bottger, K. (2016). A daptive reuse of the South B risbane M unicipal Chambers. In S. Y. M ehr (Ed.), PhD . A ustralia, Queensland: G riffith University Gold Coast Campus.

Bullen, P. A., \& Love, P. E. (2011). A daptive reuse of heritage buildings. Structural Survey, 29(5), 411-421.

Chattopadhyay, S., \& W hite, J. (2014). City halls and civic materialism: towards a global history of urban public space: Routledge.

Conejos, S. (2013). D esigning for future building adaptive reuse: B ond U niversity A ustralia.

Conejos, S., L angston, C., \& Smith, J. (2011). Improving the implementation of adaptive reuse strategies for historic buildings.

Cook. (2017a) A daptive reuse of Rockhampton City Hall//Interviewer: S. Y. M ehr. PhD, Griffith University, A ustralia.

Cook, G. (2017b). A daptive reuse of R ockhampton City Hall. In S. Y. M ehr (Ed.), PhD thesis. A ustralia: Griffith University.

Douglas, J. (2006). Building adaptation: Routledge.

J agarajan, R., A smoni, M. N . A. M ., M ohammed, A. H., Jaafar, M. N., M ei, J. L. Y ., \& B aba, M. (2017). Green retrofitting-A review of current status, implementations and challenges. Renewable and Sustainable E nergy Reviews, 67, 1360-1368.

Kelly, M. J. (2009). Retrofitting the existing UK building stock. Building Research \& Information, 37(2), 196-200.

L Marquis, A. (1992). Toowoomba City Hall: Conservation study. Retrieved from Toow oomba, A ustralia:

L angston, C. (2008). The sustainability implications of building adaptive reuse.

L angston, C. (2012). V alidation of the adaptive reuse potential (ARP) model using iconCUR. F acilities, 30(3/4), 105-123.

M artínez-M olina, A ., Tort-A usina, I., Cho, S., \& V ivancos, J.-L . (2016). Energy efficiency and thermal comfort in historic buildings: A review. Renewable and Sustainable Energy Reviews, 61, 70-85.

M aryborough Chronicle, N. (1938). ROCK HAM PTON 'S NEW TOW N HALL. Maryborough Chronicle, Wide Bay and Burnett Advertiser (QId. : 1860 - 1947).

M azzarella, L. (2015). Energy retrofit of historic and existing buildings. The legislative and regulatory point of view. Energy and Buildings, 95, 23-31. 
Menzies, G. F. (2011). Embodied energy considerations for existing buildings. Historic Scotland Technical Paper, 13.

Miller, E., \& Buys, L. (2008). Retrofitting commercial office buildings for sustainability: tenants' perspectives. J ournal of Property Investment \& F inance, 26(6), 552-561.

MTBA, M.T.B.A.A. I. (2016). BUILDING RESILIENCE: PRACTICAL GUIDELINES FOR THE SUSTAINABLE REHABILITATION OF BUILDINGS IN CANADA. Canada: Library and A rchives $C$ anada Cataloguing in Publication.

Pisello, A . L., Petrozzi, A ., Castal do, V . L., \& Cotana, F. (2016). On an innovative integrated technique for energy refurbishment of historical buildings: Thermal-energy, economic and environmental analysis of a case study. Applied energy, 162, 1313-1322.

Plevoets, B. (2014). Retail-Reuse: an interior view on adaptive reuse of buildings. Ph. D. Hasselt, B el gium: Hasselt University Press,

Sims, S. (2016). A daptive reuse of Toowoomba City Hall. In S. Y. M ehr (Ed.), PhD. Gold Coast, A ustralia: Griffith University.

Somerville, S. (2017) Adaptive Reuse of Rockhampton City Hall/Interviewer: S. Yazdanimehr. $\mathrm{PhD}, \mathrm{G}$ riffith University, A ustralia.

Taylor, S., \& Bogdan, R. (1984). Introduction to qualitative research methods: The search for meaning. In: N ew Y ork: John Wiley \& Sons.

The Brisbane Courier, N. (1892). South B risbane M unicipal Building. The Brisbane Courier (QId: 1864-1933), p. 7.

The Courier M ail, N. (1955). START ON HALL JOB. Courier Mail.

The Queensland Government, R. (2016a). South Brisbane Municipal Chambers (former). A ustralia: Queensland Government Retrieved from https://www.qld.gov.au/.

The Queensland Government, R. (2016b). Toowoomba City Hall. A ustralia: Queensland Government R etrieved from https://www.qld.gov.au/.

Toohey, D. (2017a). A daptive reuse of Rockhampton City Hall. In S. Y. M ehr (Ed.), PhD thesis. A ustralia: Griffith University.

Toohey, D. (2017b). A daptive reuse of R ockhampton City Hall. In S. Y azdanimehr (Ed.), P hD. A ustralia: Griffith U niversity.

van der Flier, K., \& Thomsen, A. (2006). Life cycle of dwellings and demolition by Dutch housing associations. Sustainable neighbourhood transformation, 11, 23-41.

V ieveen, M. (2013). A daptive energy efficiency in historic buildings. Energieke Restauratie, 108-116.

W ebb, A . L . (2017). Energy retrofits in historic and traditional buildings: A review of problems and methods. Renewable and Sustainable Energy Reviews, 77, 748-759.

Wilkinson, S. (2011). Sustainable retrofit potential in lower quality office stock in the central business district. Paper presented at the M ISBE 2011: Proceedings of the International Conference on $M$ anagement and Innovation for a Sustainable Built Environment.

Wilkinson, S., Remøy, H., \& Langston, C. (2014). Sustainable building adaptation: innovations in decision-making: J ohn Wiley $\&$ Sons.

Wills, J. (2011). Mossman Shire Hall \& Douglas Shire Council Chambers (former) : conservation plan for Cairns Regional Council. Queensland: Cairns.

Y azdani M ehr, S., Holden, G., \& Skates, H. (2016). A dding M ore by U sing Less: A daptive Reuse of Woolstores. SBE16 Sydney: International High-Performance Built Environments Conference.

Y in, R. K. (2017). Case study research and applications: Design and methods: Sage publications.

Zainal, Z. (2017). Case study as a research method. J urnal Kemanusiaan, 5(1). 


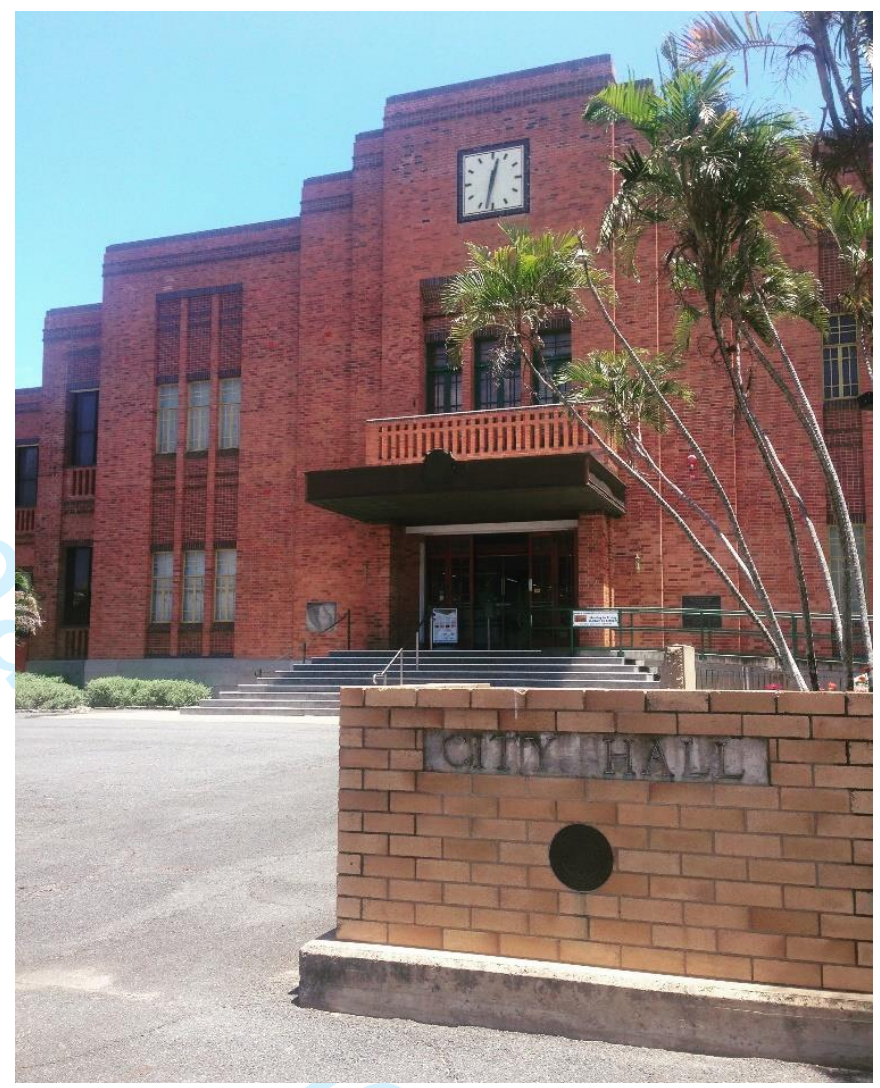

Figure 1 Rockhampton City Hall, 2017 (Source: Author) 


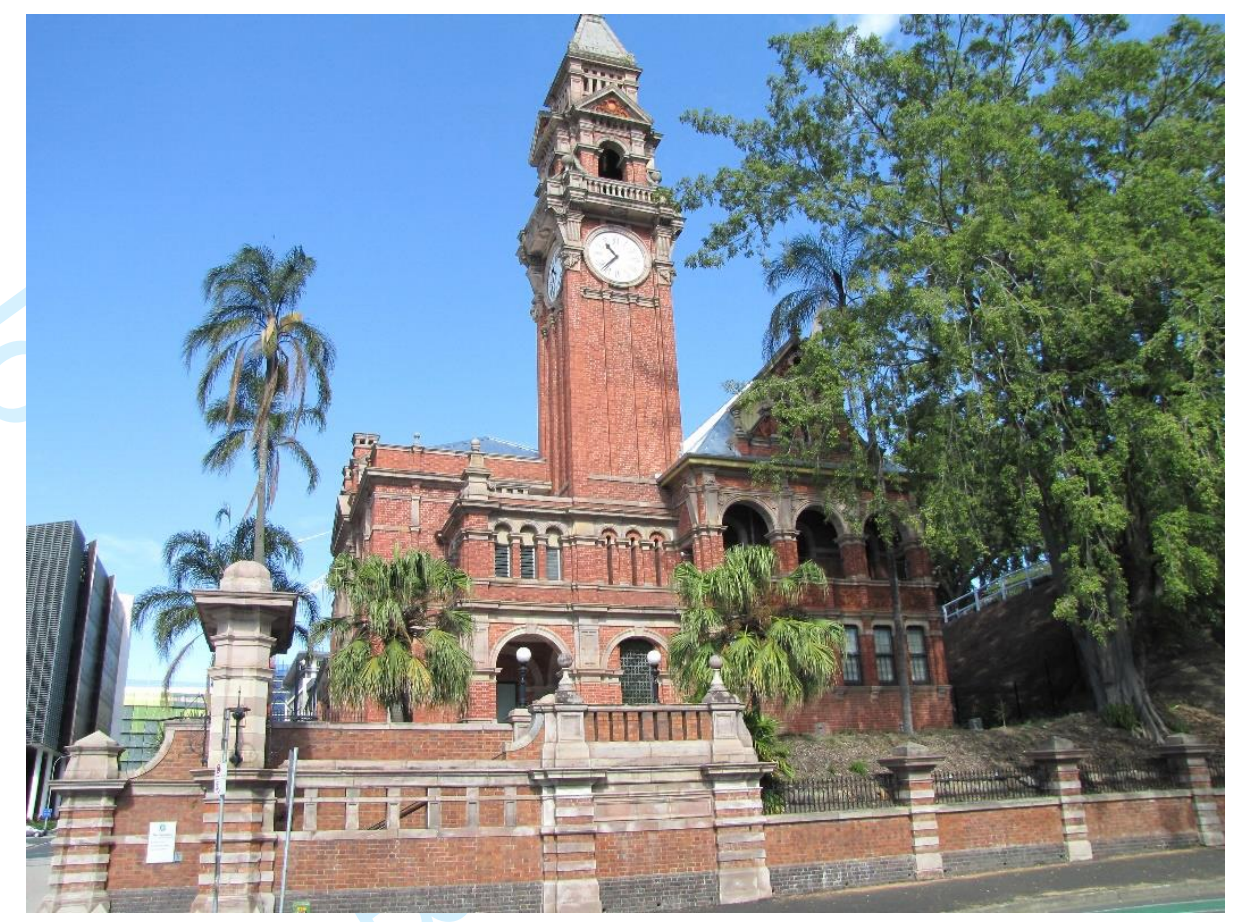

Figure 2 South Brisbane Municipal Chambers, 2017 (Source: Author) 


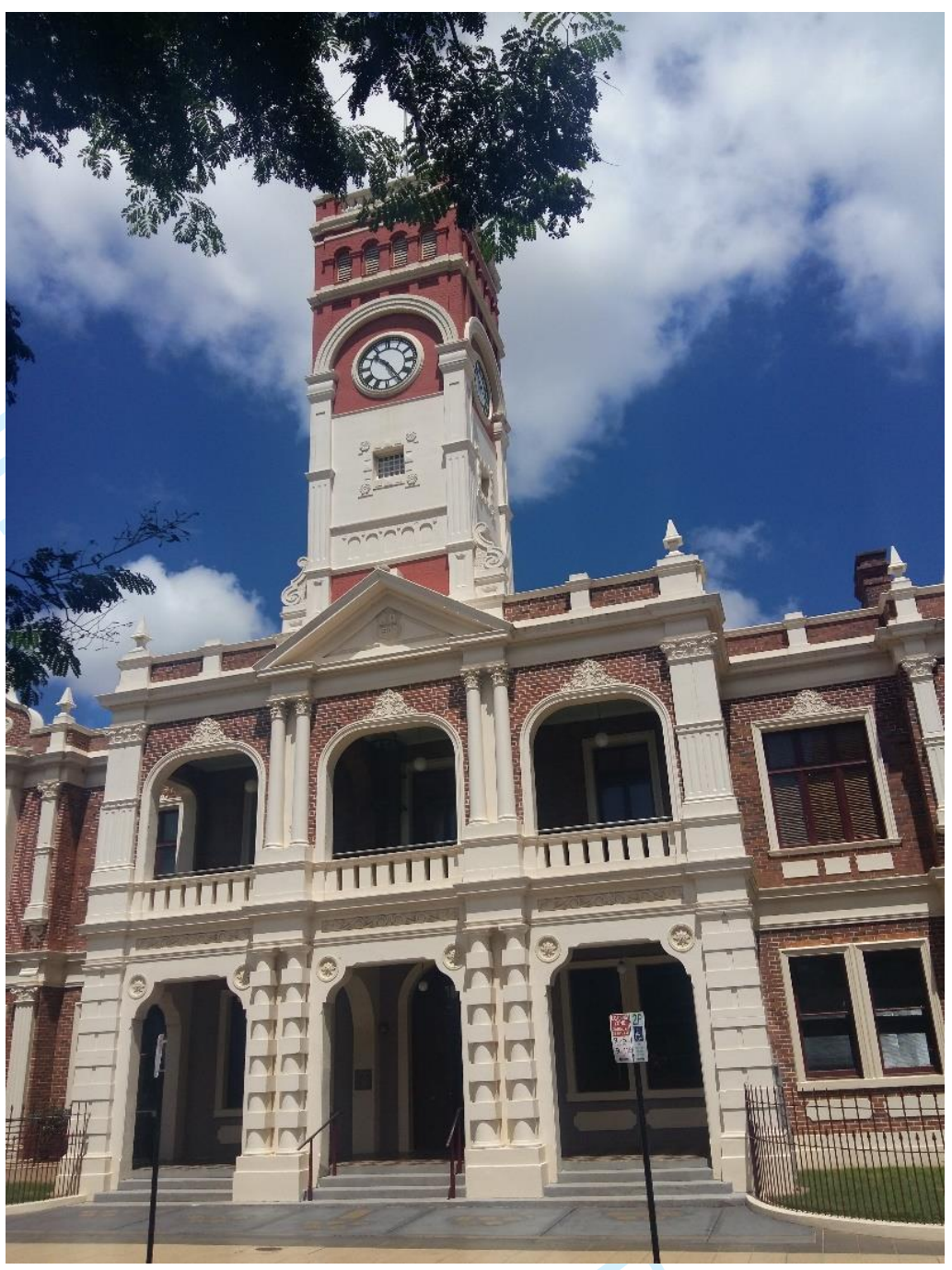

Figure 3 Toowoomba City Hall, 2017 (Source: Author) 
Table 1 Classification of technical issues of adaptive reuse (Plevoets, 2014)

\begin{tabular}{|c|c|}
\hline \multicolumn{2}{|c|}{ Technical challenges of adaptive reuse } \\
\hline Loadbearing structure & $\begin{array}{ll}\text { - } & \text { Frames (timber, concrete, steel) } \\
\text { - } & \text { Floors } \\
\text { - } & \text { Roofs } \\
\text { - } & \text { Walls } \\
\text { - } & \text { Heavy lifting } \\
\text { - } & \text { underpinning } \\
\end{array}$ \\
\hline Building envelop & $\begin{array}{ll}\text { - } & \text { Internal surfaces } \\
\text { - } & \text { Introduction of new floors } \\
\text { - } & \text { Façade } \\
\text { - } & \text { Accessibility and circulation }\end{array}$ \\
\hline Comfort, safety, energy efficiency & $\begin{array}{ll}\text { - } & \text { Fire resistance } \\
\text { - } & \text { Thermal Performance } \\
\text { - } & \text { Acoustic performance } \\
\text { - } & \text { Pndoor air quality } \\
& \text { Preventing moisture and dampness }\end{array}$ \\
\hline
\end{tabular}


Table 2 Building adaptation and technical challenges of Rockhampton City Hall (Author, 2018)

\begin{tabular}{|c|c|}
\hline Building adaptation & Technical challenges \\
\hline $\begin{array}{c}\text { Enclosed verandas around the } \\
\text { building }\end{array}$ & $\begin{array}{l}\text { - Sealing of the whole building obstructing received natural lights } \\
\text { and ventilation } \\
\text { - Installation of poor window glazing system, which impacted } \\
\text { negatively on the general condition of the building and created } \\
\text { a degraded and unventilated work environment }\end{array}$ \\
\hline $\begin{array}{l}\text { Installation of air-conditioning } \\
\text { systems }\end{array}$ & $\begin{array}{l}\text { - Interference with the original building by providing several } \\
\text { ducts, units, cables, and drainage canals. } \\
\text { - Difficulty in finding a suitable location for heavy AC equipment } \\
\text { - Installation of a large air-conditioning plant on the north-west } \\
\text { courtyard has a negative effect on the building visually. }\end{array}$ \\
\hline $\begin{array}{c}\text { Installation of electrical equipment } \\
\text { and lighting }\end{array}$ & - Preserving architectural integrity of the building \\
\hline $\begin{array}{c}\text { Installation of telecommunications } \\
\text { equipment }\end{array}$ & - Preserving architectural integrity of the building \\
\hline
\end{tabular}


Table 3 Building adaptation and technical challenges of SBMC (Author, 2018)

\begin{tabular}{|c|c|}
\hline Building adaptation & Technical challenges \\
\hline $\begin{array}{l}\text { Installation of ventilation and } \\
\text { soundproofing systems }\end{array}$ & $\begin{array}{l}\text { - Soundproofing was inadequate } \\
\text { - The air ventilation system did not ventilate the rooms very } \\
\text { well, and even carried sound from room to room as well as air } \\
\text { - There was no air-conditioning system, so doors and windows } \\
\text { needed to be open in rooms, which resulted in environmental } \\
\text { noise from both the building and the environment. }\end{array}$ \\
\hline $\begin{array}{l}\text { Installation of fans hanging } \\
\text { from false ceiling }\end{array}$ & - Damage to the architectural integrity of the building \\
\hline $\begin{array}{l}\text { Installation of portable ventless } \\
\text { air conditioning systems }\end{array}$ & $\begin{array}{l}\text { - Difficulty achieving "invisibility" } \\
\text { - Preserving architectural integrity of the building }\end{array}$ \\
\hline
\end{tabular}


International Journal of Building Pathology and Adaptation

Page 18 of 20

1

2

3

4

5

6

7

8

9

10

11

12

13

14

15

16

17

18

19

20

21

22

23

24

25

26

27

28

29

30

31

32

33

34

35

36

37

38

39

40

41

42

43

44

45

46

47

48

49

50

51

52

53

54

55

56

57

58

59

60
Table 4 Building adaptation and technical challenges of Toowoomba City Hall (Author, 2018)

\begin{tabular}{cclll}
\hline Building adaptation & \multicolumn{3}{l}{ Technical challenges } \\
\hline $\begin{array}{c}\text { Improving ventilation systems and installing } \\
\text { skylights in the art gallery to provide natural light }\end{array}$ & $\bullet \begin{array}{l}\text { Preserve heritage characteristics of the } \\
\text { building }\end{array}$ \\
\hline $\begin{array}{c}\text { Installing mechanical air-conditioning to improve } \\
\text { indoor air quality and meet user expectations }\end{array}$ & $\bullet$ & Difficulty in getting the equipment in & \\
\hline Installing insulation and acoustic & $\bullet \begin{array}{l}\text { Preserve heritage characteristics of the } \\
\text { building }\end{array}$ &
\end{tabular}

1 
Page 19 of 20

International Journal of Building Pathology and Adaptation

1

2

3

4

5

6

7

8

9

10

11

12

13

14

15

16

17

18

19

20

21

22

23

24

25

26

27

28

29

30

31

32

33

34

35

36

37

38

39

40

41

42

43

44

45

46

47

48

49

50

51

52

53

54

55

56

57

58

59

60
Table 5 Technical challenges of adaptation of three case studies (Author, 2018)

\begin{tabular}{lccccc}
\hline \multicolumn{1}{c}{ Three Case Studies } & \multicolumn{3}{c}{ Technical Challenges of adaptation } \\
\cline { 2 - 5 } & Air-Conditioning & Insulation & Acoustics & Lighting \\
\hline Rockhampton City Hall & $\checkmark$ & $\times$ & $\times$ & $\times$ \\
\hline South Brisbane Municipal Chambers & $\checkmark$ & $\times$ & $\checkmark$ & $\times$ \\
\hline Toowoomba City Hall & $\checkmark$ & $\checkmark$ & $\checkmark$ & $\times$ \\
\hline
\end{tabular}


Table 6 Technical analysis of three case studies (Author, 2018)

\begin{tabular}{|c|c|c|c|}
\hline City Halls & $\begin{array}{c}\text { Inherent energy efficient } \\
\text { services }\end{array}$ & $\begin{array}{c}\text { Technical Changes and } \\
\text { challenges }\end{array}$ & $\begin{array}{l}\text { Key strategies for energy } \\
\text { efficient adaptation }\end{array}$ \\
\hline Rockhampton City Hall & $\begin{array}{l}\text { - Open verandas to provide } \\
\text { natural ventilation } \\
\text { - Windows on four façades } \\
\text { to provide natural light } \\
\text { - Heavy masonry external } \\
\text { walls with high thermal } \\
\text { mass }\end{array}$ & $\begin{array}{l}\text { - Enclosed verandas led } \\
\text { to the installation of } \\
\text { air-condition and new } \\
\text { lighting } \\
\text { - Finding a location for } \\
\text { the AC equipment due } \\
\text { to its heavy loads } \\
\text { - Installation of AC on } \\
\text { the north-west façade } \\
\text { has a negative effect on } \\
\text { the building visually } \\
\text { - Installation of LED } \\
\text { lights }\end{array}$ & $\begin{array}{l}\text { - Convert the building to its } \\
\text { original state to utilise its } \\
\text { original features for passive } \\
\text { heating and cooling schemes } \\
\text { - Modify energy efficient } \\
\text { mechanical and electrical } \\
\text { systems } \\
\text { - Upgrade and re-install original } \\
\text { doors and windows } \\
\text { - Repoint mortar joints to } \\
\text { provide an efficient air barrier } \\
\text { and reduce the risk of rain } \\
\text { penetration }\end{array}$ \\
\hline $\begin{array}{c}\text { South Brisbane Municipal } \\
\text { Chambers }\end{array}$ & $\begin{array}{l}\text { - Large windows on four } \\
\text { façades provided natural } \\
\text { light and ventilation } \\
\text { - Stained-glass window } \\
\text { provided natural light for } \\
\text { main staircase } \\
\text { - Repairable wood frame } \\
\text { windows } \\
\text { - Heavy masonry walls } \\
\text { with good thermal mass }\end{array}$ & $\begin{array}{l}\text { - Destruction of interior } \\
\text { walls and ceiling for } \\
\text { installation of } \\
\text { ventilation and } \\
\text { soundproofing systems } \\
\text { - Installation of air } \\
\text { conditioning and } \\
\text { difficulty to find a } \\
\text { suitable place to getting } \\
\text { the equipment in } \\
\text { - Installation of LED } \\
\text { lights }\end{array}$ & $\begin{array}{l}\text { - Keep and maintain timber } \\
\text { frame windows by providing } \\
\text { thermal-panes and energy } \\
\text { panels } \\
\text { - Upgrade mechanical and } \\
\text { electrical systems based on } \\
\text { user needs } \\
\text { - Add significant insulation to } \\
\text { the interior walls } \\
\text { - Repoint mortar joints to } \\
\text { provide an efficient air barrier } \\
\text { - Improve thermal performance } \\
\text { of windows }\end{array}$ \\
\hline Toowoomba City Hall & $\begin{array}{l}\text { - Windows on different } \\
\text { façades to provide natural } \\
\text { light and ventilation } \\
\text { - Thick walls with thermal } \\
\text { mass } \\
\text { - Panels and wallpapers } \\
\text { behind walls provided } \\
\text { acoustic and insulation }\end{array}$ & $\begin{array}{l}\text { - Extend the building in } \\
\text { two sides blocked the } \\
\text { windows. Skylight was } \\
\text { provided for natural } \\
\text { light } \\
\text { - Installation of air } \\
\text { conditioning and } \\
\text { difficulty to find a } \\
\text { suitable place to getting } \\
\text { the equipment in } \\
\text { - Installation of LED } \\
\text { lights }\end{array}$ & $\begin{array}{l}\text { - Provide acoustic materials } \\
\text { which have high density and } \\
\text { act as an insulation as well } \\
\text { - Upgrade mechanical and } \\
\text { electrical systems to meet user } \\
\text { requirements } \\
\text { - Installation of polycarbonate } \\
\text { window frames } \\
\text { - Improve thermal performance } \\
\text { of walls internally } \\
\text { - Improve internal envelope }\end{array}$ \\
\hline
\end{tabular}

